九州大学学術情報リポジトリ

Kyushu University Institutional Repository

Research Note on Brahmanical Deities in Mikkyō Astrological Art

Kotyk, Jeffrey

https://doi.org/10.5109/2231635

出版情報: Journal of Asian Humanities at Kyushu University. 4, pp.101-108, 2019-03. Kyushu University, School of Letters, Graduate School of Humanities, Faculty of Humanities バージョン:

権利関係 : 


\title{
Research Note on Brahmanical Deities in Mikkyō Astrological Art
}

\author{
JEFFREY KOTYK
}

\section{Introduction}

$\mathbf{A}$ $\mathrm{N}$ ancient manuscript titled Goma rodan yō 護摩爐壇樣 (Model for the Homa Altar) is found in volume seven of the modern compilation of images, the Taishō zuzō 大正圖像. ${ }^{1}$ This same title appears in the catalog of texts brought back from China by the Japanese monk Jōgyō 常曉 (d. 867) in 839, hence the document at hand was originally a Chinese composition. ${ }^{2}$ Here I would like to draw attention to the icons therein of the naksatras (lunar mansions, that is, constellations along the orbital path of the Moon) in anthropomorphic forms and their relationship to the Brahmanical deities associated with the naksatras described in the Japanese recension of the Xiuyao jing (Jp. Sukuyō-kyō 宿曜經; Sutra of Constellations and Planets). ${ }^{3}$ We will then examine these same deities as they

1 Goma rodan yō, T zuzō, vol. 7, pp. 815-41.

2 This document is discussed in Kotyk, "The Sinicization of IndoIranian Astrology," pp. 14-15.

3 As Yano Michio has explored, there are two recensions of the Xiuyao jing: the Japanese and the Chinese recensions. The former line is traced back to manuscripts brought to Japan by monks such as Kūkai 空海 (774-835), and best represents the original text in contrast to the latter, which displays a number of significant modifications. See Yano, "'Sukuyō-kyō' no Daizōkyō," pp. 6-10. are portrayed in later "star mandalas" (hoshi mandara 星曼荼羅) from the Japanese medieval period, a time when horoscopy - an art monopolized by a community of monks called Sukuyōdō 宿曜道－flourished among the Japanese aristocracy. ${ }^{4}$

\section{Historical Background}

Early Buddhists in India observed the lunar cycle as a means of coordinating their ecclesiastical schedule, and to determine astrologically auspicious days to carry out practices or ceremonies. The lunar phases were divided into two periods ( $p a k s a$ ), each comprised of fifteen days, called tithis (a day running from sunrise to sunrise), namely the śukla-pakșa (waxing period) and krșna-pakșa (waning period). In addition, the orbital path of the Moon was divided into twenty-eight or twenty-seven lunar stations of varying dimensions called naksatras.

The earliest datable Buddhist text that explains na$k s$ atras and the astrological lore of each of them is the

4 The introduction of astrology and its related practice of astral magic have been documented in Kotyk, "Japanese Buddhist Astrology and Astral Magic." For an earlier study, see Momo, "Sukuyōdō to sukuyō kanmon." 
Sầrdūlakarnāvadāna, which was likely produced in Magadha (a region roughly corresponding to modern Bihar state in India) during the third century CE. This work was first translated into Chinese between 307-313 by Dharmarakșa 笑法護 as the Shetoujian Taizi ershiba xiu jing 舍頭諫太子二十八宿經 (T 1301) or Sūtra of Prince Sārdūlakarna and the Twenty-Eight Nakșatras. A separate recension, most likely stemming from Central Asia, was translated by Gunabhadra 求那咙陀羅 (394-468) as the Mātanga-sūtra 摩登伽經.5

In the Sārdūlakarnāvadāna, each nakșatra is associated with a Brahmanical deity. It is considered auspicious to make offerings to the specific deity associated with the naksatra in which the Moon is stationed. For example, the Màtanga-sūtra furnishes the following details concerning the nakșatra named Śravana (traditionally equated with the Chinese lunar station Nü 女):

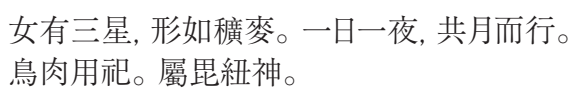

Śravana consists of three stars, shaped like a cereal grain. The Moon transits through it over the course of one day and one night. Offer fowl as a sacrifice. [Śravana] is associated with the god Vișnuu. ${ }^{6}$

The presence of such Vedic deities indicates that naksatra astrology was non-Buddhist in origin, although it was observed by Buddhists.

The Mahāsamnipāta 大方等大集經 (T 397), a collection of various Buddhist scriptures, includes the Candragarbha-parivarta 月藏分 and Sūryagarbhaparivarta 日藏分, translated by Narendrayaśas 那連提 耶舍 (490-589) in the years 566 and 585 respectively. These two texts explain some astrology, albeit with errors. In the Süryagarbha-parivarta, Srāvana as the name of a month is conflated with a different naksatra called Punarvasū, and furthermore is associated with the "solar deity" ( $r$ i tian 日天). Curious as such an anomaly might be, it does not appear that Chinese Buddhists observed any type of naksatra astrology until the eighth century when Mantrayāna was introduced.

5 Mātaniga-sūtra, pp. 399-410. For further details, see Kotyk, "Buddhist Astrology and Astral Magic in the Tang Dynasty," pp. 55-58.

6 Mātaniga-sūtra, p. 405a.
Śubhakarasimha 善無畏 (637-735) and his team, which included the eminent astronomer-monk Yixing 一行 (673-727), translated the Vairocanäbhisambodhi or ${ }^{*}$ Mahāvairocana-sūtra (Dari jing 大日經; T 848) in 724. Yixing compiled a commentary to the text based upon the oral remarks of Subhakarasimha sometime before 727, which became the Dari jing shu 大日經疏 (T 1796). This commentary explains the essential features of Indian hemerology as Śubhakarasimha understood it, but it lacks sufficient detail to be able to determine an auspicious time to create a mandala without recourse to Sanskrit texts or an Indian specialist.?

The absence of an accessible manual of Indian astrology in Chinese likely motivated Amoghavajra 不空 (705-774) to compile the Xiuyao jing, first in 759 and with a subsequent revision in $764 .{ }^{8}$ Amoghavajra compiled this text from disparate and evidently non-Buddhist sources. He then attributed its authorship to Mañjuśrī Bodhisattva, likely as a means of validating the text for Buddhist use in China, especially in light of the many elements in the text that are antithetical to Buddhist precepts, such as encouraging the production of weapons and alcohol on specific days. Other evidently non-Buddhist elements in the text are Brahmanical deities.

\section{Brahmanical Deities in the Xiuyao jing and Goma rodan yō}

The 764 version of the Xiuyao jing lists primarily Vedic deities in two sections (no illustrations are present in either recension of the text). The first set is found in chapter 2, which explains each of the twenty-eight na$k$ satras, including their respective shapes and number of stars, in addition to their associated deities, gotras, and foods. The text also describes the activities to be done or avoided when the Moon converges with each of the naksatras, as well as providing predictions about the personalities and fortunes of people born under each of them. These features are similar to the Śârdūlakarnāvadāna, but not identical. The second set of Vedic deities is listed in chapter 6 . These are deities associated with each of the tithis in a pakșa. Each deity is believed

7 The astrology in this commentary is discussed in Kotyk, "Early Tantric Hemerology in Chinese Buddhism."

8 The first fascicle of the text is the 764 version, while the second is the 759 version. Yano, Mikkyō senseijutsu, p. 264. 


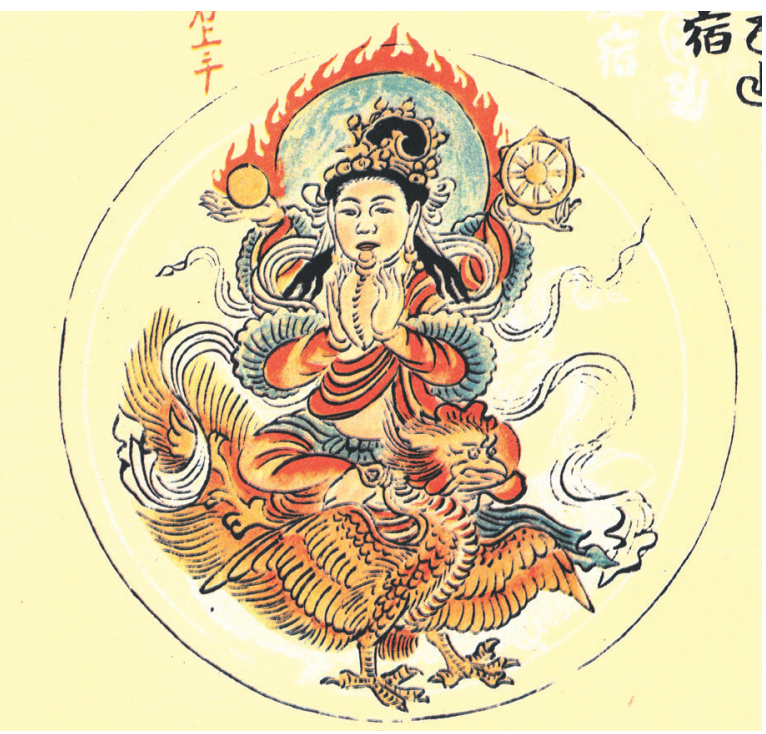

Figure 1. Urukiboshi in Goma rodan yō. T zuzō 31637 (appended item no. 43)

to descend into the world on the tithi associated with it.

The first set is our present concern, given its clear connections to the aforementioned Goma rodan yō. One striking parallel between this text and the Xiuyao jing is the nakșatra Sravana, which as noted above is associated with Viṣnu in the Mātainga-sūtra. This is also so in the Xiuyao jing, in which the associated deity of Urukiboshi (the Japanese name for the Chinese lunar station Nü, which is used as an equivalent for Śravaṇa) is named Bisōjū-shin 毗藪紐神 (the god Viṣnu). ${ }^{9}$ Turning to the Goma rodan yō, we see Urukiboshi/ Nü in an illustrated form (figure 1). The traditional attributes of Vișnu are apparent here: the four arms, conch (śankha), flaming wheel (sudarśana-cakra), and the garuda mount (vahana). This association between Viṣnu and Sravana is relatively ancient, given that the Nakșatrakalpa of the Atharvavedapariśiștā (4.6) gives an identical assignment ("śravaṇe viṣnur ucyate"). ${ }^{10}$

Another notable example is that of Ārdrā, or in Japanese, Karasukiboshi (Ch. Shen 參). The Xiuyao jing associates this nakṣatra with Rodatsura-shin 魯達羅 神 (the god Rudra). Similarly, the Atharvavedapariśișța (4.2) also gives Rudra ("rudrasyā ārdrā"). ${ }^{11}$ The icon in this context is reflective of the god Siva and his reclin-

9 Sukuyō-kyō shukusatsu 宿曜經縮刷, vol. 1, p. 23.

10 Atharvavedapariśișțā, p. 4.

11 Ibid., p. 3. Sukuyō-kyō shukusatsu, vol. 1, p. 17.

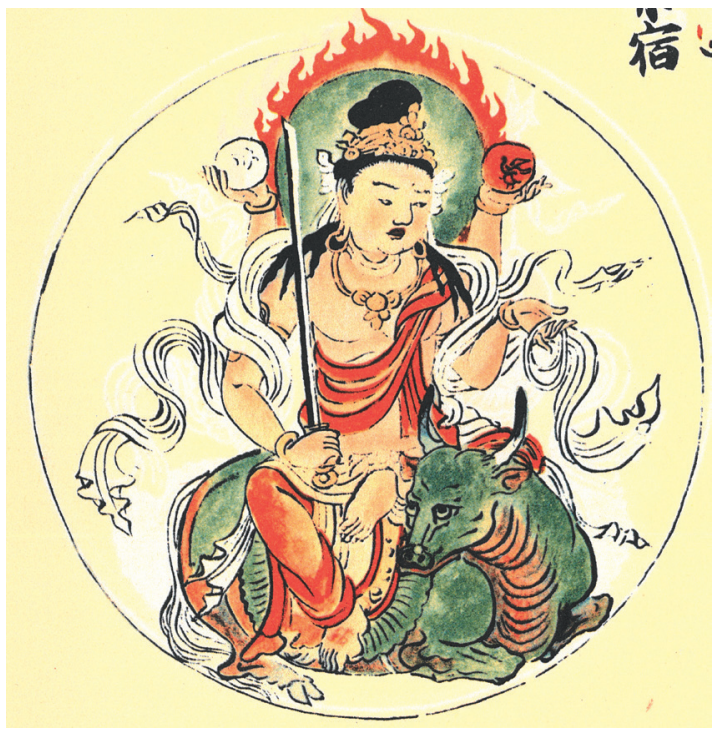

Figure 2. Karasukiboshi in Goma rodan yō. T zuzō 31637 (appended item no. 26).

ing bull, nowadays commonly called Nandi (figure 2). Rudra is one of the names of Siva. Rudra is also considered to be the predecessor of Siva in the Vedas. ${ }^{12}$

We must note that the nakșatra deities in the Taizō $z u z \bar{o}$ 胎藏圖象, which represent the original icons of the taizōkai mandala 胎藏界曼荼羅 (the “Womb Matrix Mandala” or Garbhadhātu-mandala), are uniformly male and bodhisattva-like in appearance with otherwise few distinguishing features. The Genzu mandara 現圖曼荼羅, the mandala of the Taizōkai used in Shingon, uses this set of Indian Buddhist icons, which differs from those of the Brahmanical set. ${ }^{13}$ The twenty-eight nakșatras in anthropomorphic forms are found in the “Outermost Court” 最外院 of the Taizōkai. There is nothing in the Mahāvairocana-sütra or its commentary to indicate that the nakșatra deities of the Taizōkai are connected with specific Brahmanical deities, especially considering that Brahmanical deities, such as Maheśvara 大自在天 (Śiva) and Śakra 帝釋天 (Indra), are already present as individual icons in the Outermost Court. ${ }^{14}$ The Brahmanical icons under present investigation therefore stem from a separate line of transmission that was arguably non-Buddhist, which is reasonable to assume in light of the fact that Amogha-

12 Bisschop, "Śiva," p. 741.

13 See Somekawa, Mandara zuten, pp. 170-239.

14 Ibid., 178, 208 


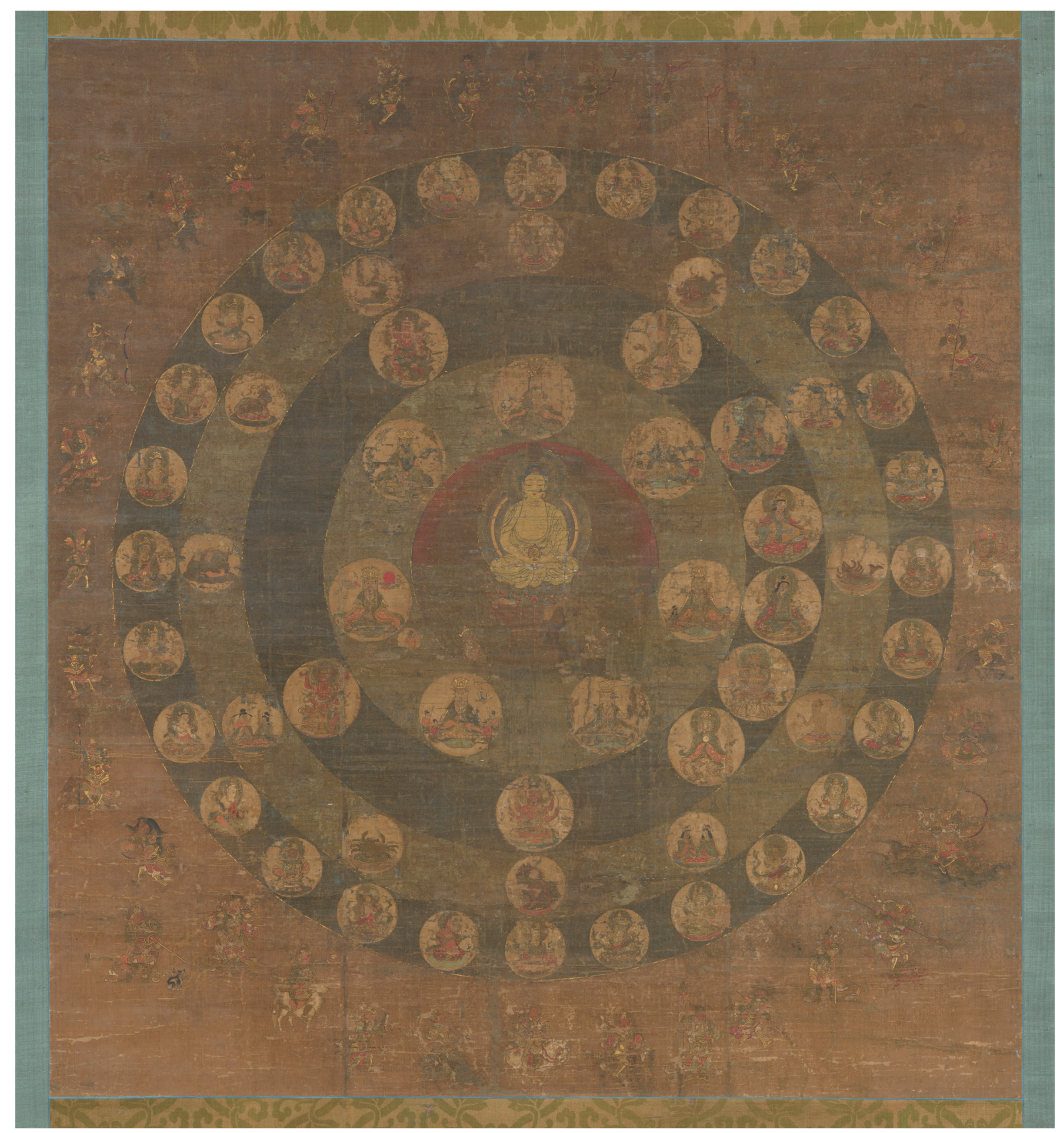

Figure 3. Star mandala. $791 / 8 \times 48$ 13/16 in. $(201 \times 124$ cm). The Metropolitan Museum of Art, New York; Promised Gift of Sue Cassidy Clark, in honor of Bernard Faure, with permission to publish.

vajra produced the Xiuyao jing from clearly non-Buddhist sources. ${ }^{15}$ The Xiuyao jing, we must iterate, does

15 The Xiuyao jing lists prescriptions for alcohol and weapon production according to an astrological schedule. This is clearly reflective of non-Buddhist sources, although the text itself never not appear to have ever included visual icons.

names these works since it is attributed to Mañjuśrī Bodhisattva. See Kotyk, "Can Monks Practice Astrology?", pp. 511-12. 


\section{- Star Mandalas}

Apart from the Goma rodan yō, these specific nakșatra icons of the Brahmanical type also appear in star mandalas (hoshi mandara). These are a unique Japanese development commencing from the mid-Heian period (794-1185). They normally display an array of astral deities (planets, zodiacs, naksatras, the seven stars of the Big Dipper, etc.) surrounding a buddha. ${ }^{16}$ These were incorporated into Mikkyō practices during the medieval period, the aim being to placate or appease the deities depicted therein. Buddhist astrologers from the Sukuyōdō community, which itself was strictly neither associated with Tōmitsu 東密 (Shingon Esoteric Buddhism) nor Taimitsu 台密 (Tendai Esoteric Buddhism), cast horoscopes and subsequently advised their clients to make offerings to specific astral deities that were determined to govern fortune and fate, based upon the client's natal chart. ${ }^{17}$ Star mandalas, I argue, appear to have been connected to this practice. ${ }^{18}$

Sukuyōdō was a lineage of Buddhist astrologer-monks active from the late tenth to the fourteenth century, sometimes competing with Onmyōdō 陰陽 道 (yin-yang practices). ${ }^{19}$ The former practiced horoscopy, while the latter worked primarily with divination methods sourced from native Chinese materials. Why suspect a link between star mandalas and Sukuyōdō? A noteworthy example of a star mandala in the collection of The Metropolitan Museum of Art, New York is important in this regard. In it, the positions of the planets in the mandala, represented in anthropomorphic forms of the Iranian-Mesopotamian type, do not appear to be

16 Star mandalas appear in circular and rectangular forms. A comprehensive study of these was carried out by Takeda Kazuaki. He briefly mentions the icons of the Goma rodan yō in Hoshi mandara no kenkyū, p. 192. An important illustrated manuscript depicting astral deities-which itself is not a mandalathat functioned as an essential foundation for star mandalas is the Fantian huoluo jiuyao 梵天火羅九㽗 ( ${ }^{\star}$ Brahmadeva-horānavagraha; T 1311). This work is spuriously attributed to Yixing but dates to the ninth century. For details on this text, see Kotyk, "Yixing and Pseudo-Yixing," pp. 16-20.

17 A natal chart is a table indicating the positions of the planets at the time of a person's birth. An astrologer uses this to make predictions about the person's fate. This practice of prescribing worship of specific astral deities is seen in medieval Japanese horoscopes. See Kotyk, "Japanese Buddhist Astrology and Astral Magic," pp. 64-65

18 For a relevant study of these mandalas, see Aruga, "Hoshi mandara to Myōken Bosatsu."

19 For a recent survey and introduction to Onmyōdō, see Yamashita Katsuaki's Onmyōdō no hakken. placed at random; rather, they reflect the planetary positions at a specific point in time (figure 3 ).$^{20}$ Other star mandalas do not generally show such configurations. ${ }^{21}$

In the Metropolitan Museum's painting, Saturn is in Capricorn, Jupiter is in Sagittarius, Mars is in Leo, the Sun is in Libra, Venus is in Scorpio, Mercury is in Libra or Scorpio, the Moon is in Libra, Rāhu is in Pisces, and Ketu is in Gemini. I was able to determine that this configuration corresponds approximately to the date 3 October 1225 , give or take a few days, and likely around 21:00, assuming that the Sun in the painting is positioned relative to the hour in question. This dating is relatively straightforward, since first we look at the years in which Saturn is in Capricorn and Jupiter is in Sagittarius. On 3 October 1225 we find the following configuration: Sun in Libra, Mercury in Libra, Venus in Scorpio, Mars in Leo, Jupiter in Sagittarius, Saturn in Capricorn, ascending node (Rāhu) in Pisces, and lunar apogee (Ketu) in Gemini. ${ }^{22}$ We ought to ignore the position of the Moon in the painting (it was actually in Cancer, not in Libra), since East Asian horoscopes from the medieval period-Chinese and Japanese-fail to accurately calculate the position of the Moon, due to the absence of accurate calculations of the apsidal precession in relation to the lunar orbit. Ketu in Japanese horoscopy is uniquely the lunar apogee, rather than the descending node of the Moon. ${ }^{23}$

Assuming that this star mandala in question represents a natal horoscope, we might imagine that the time of birth of the client specifically was illustrated in this fashion, and thus it was likely produced sometime between 1225 and 1325. The Metropolitan Museum of Art dates this mandala to the second half of the fourteenth century. This mandala would have been produced for ritual purposes, specifically as a means

20 "Iranian-Mesopotamian" is a designation given to one set of icons of planetary deities. These were the most widely used in East Asia. They are seen in Chinese, Tangut, Korean, and Japanese contexts after the early ninth century. See Kotyk, "Astrological Iconography of Planetary Deities in Tang China," pp. 46-48. I utilized the ephemerides at www.astro.com. See also Tuckerman, Planetary, Lunar, and Solar Positions, p. 630.

21 The work is Star Mandala, accession number L.2013.4a-d. Elizabeth Tinsley, a Metropolitan Museum of Art research fellow at the time, originally approached me with this specimen and, suspecting it was reflective of a horoscope, asked if I could calculate its date on the basis of the planetary configurations relative to zodiac signs.

22 In calculating these planetary positions, I utilized the ephemerides at www.astro.com.

23 Yano, Mikkyō senseijutsu, pp. 186-87. 


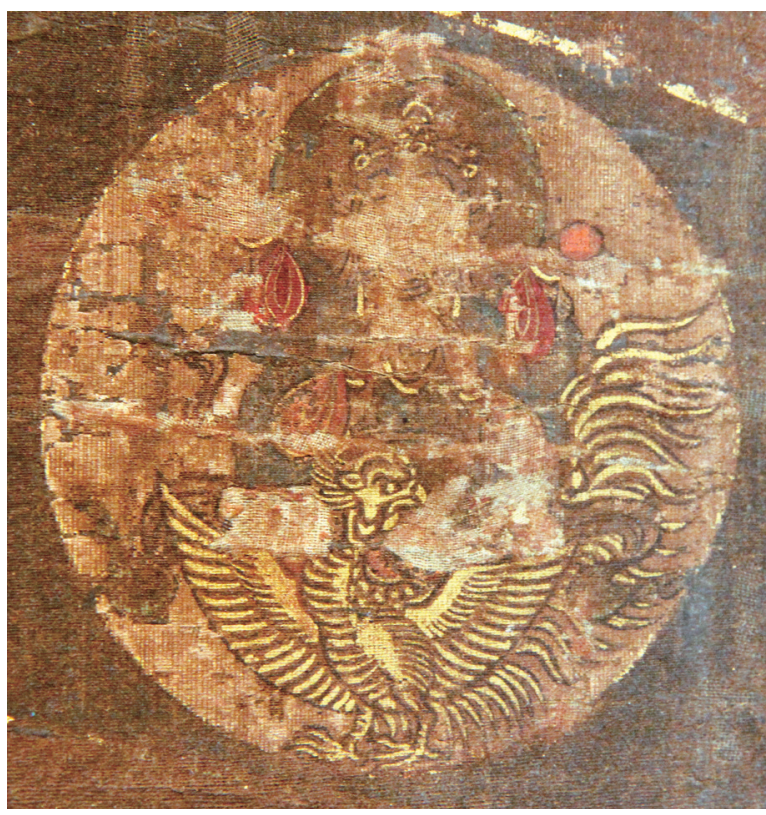

Figure 4. Urukiboshi, detail in Star mandala. The Metropolitan Museum of Art, New York; Promised Gift of Sue Cassidy Clark, in honor of Bernard Faure. Photograph by Elizabeth Tinsley.

to counteract unfavorable prognostications connected uniquely to the client, but an ordinary Mikkyō monk would not have had the tools or knowledge available to produce a horoscope, since such technical expertise in medieval Japan was limited to Sukuyōdō. Only a Sukuyōshi 宿曜師 (a master astrologer of the Sukuyōdō lineage), trained in basic calendrical science and in possession of the necessary tables (ephemerides showing planetary positions over time), could have made the necessary calculations. The identities of both the astrologer and client in the present context, however, remain uncertain.

The Brahmanical deities as lunar stations described above also appear in this mandala, such as Urukiboshi/ Sravana. Although the section with this divinity is slightly damaged in the painting, it is clearly modelled after the same motif seen in the Goma rodan yō, with the garuda especially visible, as seen in figure 1.

With respect to other examples, the Philadelphia Museum of Art (\#1978-45-2) possesses a pristinely preserved star mandala dated to the Edo period in which the Brahmanical icons are depicted. Their presence here reveals that this set of icons was in continual use until even the early modern period. Another relevant specimen dated to the eighteenth to nineteenth century is found at the Museum of Fine Arts, Boston (\#11.7123). This mandala in rectangular form also uses the Brahmanical icons. ${ }^{24}$

\section{Brahmanical Planetary Icons}

As a final observation, we should note that the Goma rodan $y \bar{o}$ also includes representations of the seven planets (the five visible planets plus the Sun and the Moon). The Moon rides a white goose while the Sun rides a horse. These motifs reflect the standard motifs of Candra and Sürya (the ancient Vedic deities of the Moon and Sun) respectively. The other five planets, however, are unique among the documented sets of astral icons in premodern East Asia. Most striking is that Mars rides a white lion, Saturn (his name in the manuscript also given as Kēwān from Sogdian) rides a white elephant (figure 5), and Jupiter (Urmazt) rides a bull (figure 6). These animals are not of the Iranian-Mesopotamian type that became standard across East Asia, but instead represent a unique set unattested elsewhere in East Asia, so far as I am aware. Nevertheless, with some degree of confidence we can assert that these icons are of Indian origin, given that Saturn atop an elephant and Jupiter atop an equine creature are attested in an Indian mandala published by William Jones in $1790 .{ }^{25}$ One complicating issue is that the names of the planets in the Goma rodan yō are given in Sogdian transliterated into Chinese characters. This might have been done for simple reference on the part of a scribe, since the Sogdian loanwords for the planets were widely used in China during the late Tang period. ${ }^{26}$

24 One curious feature of this painting is the depiction of Scorpio on the right side as a prawn, rather than as a scorpion. This error likely stems from a misreading of sasori 蝎 as ebi 蝦. This point illustrates that the artists who produced these pieces were not necessarily familiar with astrological lore. They seem to have worked from iconographical manuals.

25 Pingree, "Indian Planetary Images and the Tradition of Astral Magic," pp. 11-12. See appended plate 3a. See also Jones, "On the Antiquity of the Oriental Zodiack," p. 303.

26 The Sogdian names of the planets, which are transliterated into Middle Chinese, are transliterations from Middle Persian. See table 1 in Kotyk, "Iranian Elements," p. 43. 


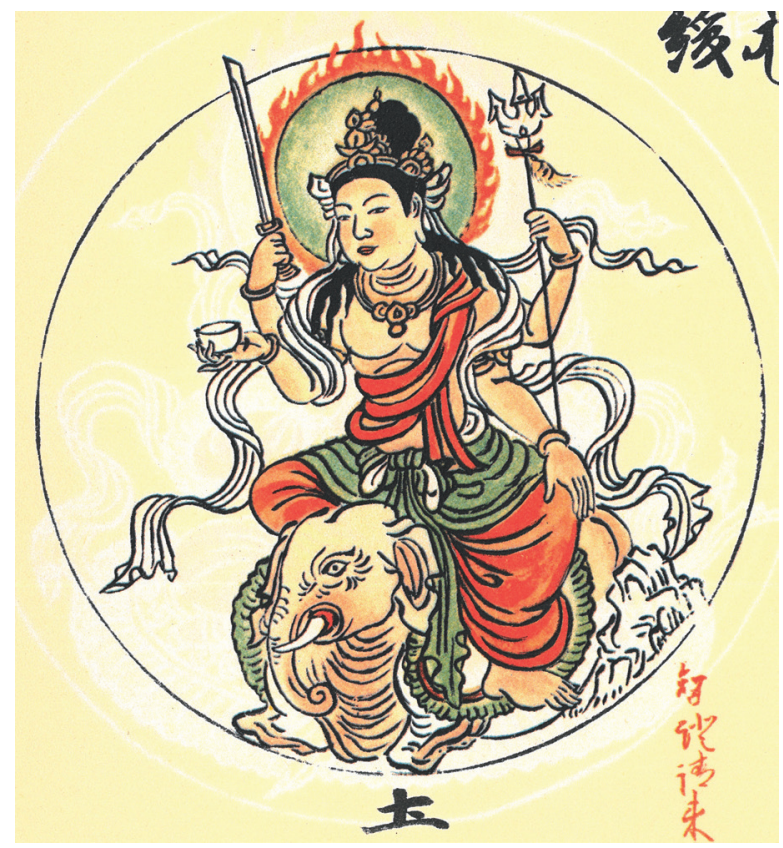

Figure 5. Saturn (Kēwān) in Goma rodan yō. TZ 31637 (appended item no. 22).

\section{Conclusion}

I propose that we call the specific set of naksatra icons connected to predominately Vedic deities "Brahmanical." This set as it exists in Japan seems to have been introduced through the Goma rodan yō, which was brought to Japan by Jōgyō in 839. These icons were often employed in star mandalas from the mid-Heian period onward. I have argued that these mandalas were, at least in some cases, produced in collaboration with monks from the Sukuyōdō community (Sukuyōshi). Last, we observed in passing that the Goma rodan yō contains five planetary icons that are unattested elsewhere in the East Asian art record, although Saturn atop an elephant and Jupiter atop a quadruped are attested in India.

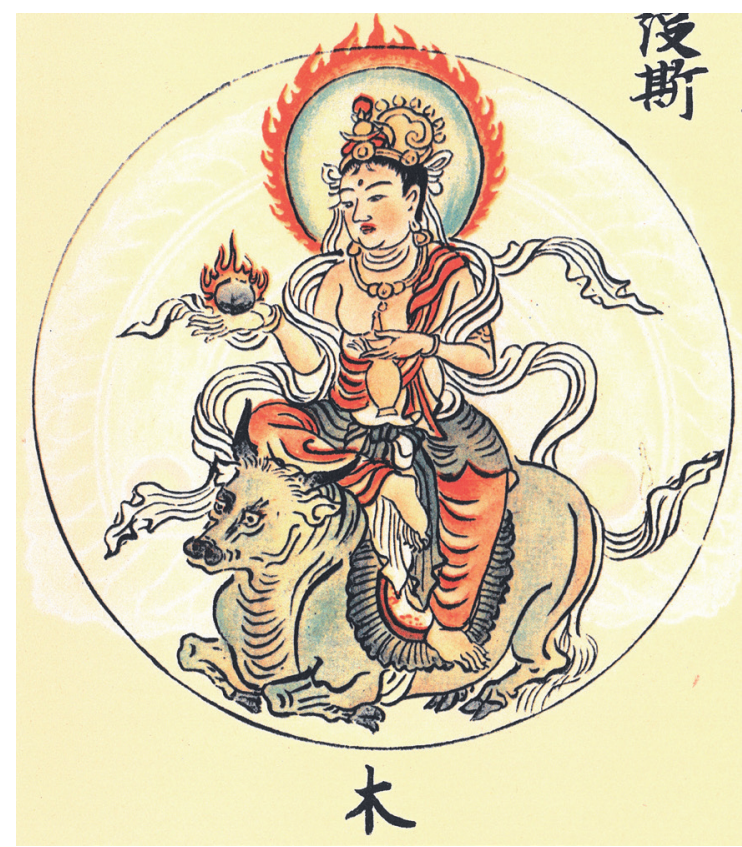

Figure 6. Jupiter (Urmazt) in Goma rodan yō. TZ 31637 (appended item no. 2).

\section{Reference List}

- Abbreviations Used

$\mathrm{T}$

Print version: Taishō shinshū daizōkyō 大正新脩大 藏經. 88 vols. Taishō Issaikyō Kankōkai, 1924-1932. Online version: SAT Daizōkyō Text database (SAT 大正新脩大蔵経 テキストデータベース ). 2018 version. University of Tokyo. http://21dzk.l.u-tokyo. ac.jp/SAT.

$\mathrm{T} z u z \bar{o} \quad$ Print version: Taishō shinshū daizōkyō zuzō 大正新 修大蔵経図像. 12 vols. Taishō Issaikyō Kankōkai, 1933-1935.

Online version: SAT Taishō zō Image Database (SAT 大正蔵図像 DB). University of Tokyo. http://dzkimgs.l.u-Tokyo.ac.jp/SATi/images.php. 


\section{- Primary Sources}

Atharvavedaparisisịtā. See The Pariśiștās of the Atharvaveda, ed. George Melville Bolling and Julius Von Negelein. Leipzig: Otto Harrassowitz, 1909.

Fantian huoluo jiuyao 梵天火羅九曜 ( ${ }^{\star}$ Brahmadeva-horānavagraha). T 1311 21: pp. 459-62.

Goma rodan yō 護摩爐壇樣. T zuzō 3163 7: pp. 815-41.

Mahāsaṃnipāta 大方等大集經. T 397 13: pp. 1-407.

Mātanga-sūtra 摩登伽經. T 1300 21: pp. 399-410.

Shetoujian Taizi ershiba xiu jing 舍頭諫太子二十八宿經. T 1301 21: pp. 410-19.

Sukuyō-kyō shukusatsu 宿曜經縮刷. 2 vols. Ed. Wakita Bunshō脇田文紹. Nagoya: Wakita Bunshō, 1897.

Taizō zuzō 胎藏圖像. T zuzō 2977 2: pp. 191-328.

Xiuyao jing 宿曜經. See Sukuyō-kyō shukusatsu.

\section{- Secondary Sources}

Aruga Takumi 有賀匠. “Hoshi mandara to Myōken Bosatsu no zuzōgaku-teki kenkyū” 星曼荼羅と妙見菩薩の圖 像學的研究. Mikkyō bunka 密教文化 2000 (204), pp. 25-63.

Begley, Wayne Edison. Viṣu's Flaming Wheel: The Iconography of the Sudarśana-cakra. New York University Press, 1973.

Bisschop, Peter. "Śiva." In Brill's Encyclopedia of Hinduism, vol. I, ed. Knut A. Jacobsen, Helene Basu, Angelika Malinar, and Vasudha Narayanan, pp. 741-54. Leiden: Brill, 2009.

Jones, William. "On the Antiquity of the Oriental Zodiack." Asiatick Researches 2 (1790), pp. 289-306.

Kotyk, Jeffrey. "Astrological Iconography of Planetary Deities in Tang China: Near Eastern and Indian Icons in Chinese Buddhism." Journal of Chinese Buddhist Studies 30 (2017), pp. 33-88.

Kotyk, Jeffrey. "Buddhist Astrology and Astral Magic in the Tang Dynasty." PhD dissertation, Leiden University, 2017.

Kotyk, Jeffrey. "Can Monks Practice Astrology? Astrology and the Vinaya in China." In Rules of Engagement: Medieval Traditions of Buddhist Monastic Regulation, ed. Susan Andrews, Jinhua Chen, and Cuilan Liu, pp. 503-17. Hamburg University Press, 2017.

Kotyk, Jeffrey. "Early Tantric Hemerology in Chinese Buddhism: Timing of Rituals According to Subhakarasimha and Yixing." Canadian Journal of Buddhist Studies 13 (2018), pp. 2-29.
Kotyk, Jeffrey. "Iranian Elements in Late-Tang Buddhist Astrology." Asia Major 30:1 (2017), pp. 25-58.

Kotyk, Jeffrey. "Japanese Buddhist Astrology and Astral Magic: Mikkyō and Sukuyōdō." Japanese Journal of Religious Studies 45:1 (2018), pp. 37-86.

Kotyk, Jeffrey. "The Sinicization of Indo-Iranian Astrology in Medieval China.” Sino-Platonic Papers 282 (2018), pp. $1-95$.

Kotyk, Jeffrey. "Yixing and Pseudo-Yixing: A Misunderstood Astronomer-Monk." Journal of Chinese Buddhist Studies 31 (2018), pp. 1-37.

Momo Hiroyuki 桃裕行. “Sukuyōdō to sukuyō kanmon” 宿 曜道と宿曜勘文. Risshō shigaku 立正史學 39 (1975), pp. $1-20$.

Pingree, David. "Indian Planetary Images and the Tradition of Astral Magic." Journal of the Warburg and Courtauld Institutes 52 (1989), pp. 1-13.

Somekawa Eisuke 染川英輔. Mandara zuten 曼荼羅圖典. Daihōrinkaku, 2013.

Takeda Kazuaki 武田和昭. Hoshi mandara no kenkyū 星曼 茶羅の研究. Kyoto: Hōzōkan, 1995.

Tuckerman, Bryant. Planetary, Lunar, and Solar Positions, A.D. 2 to A.D. 1649 at Five-day and Ten-day Intervals. Philadelphia: American Philosophical Society, 1964.

Yamashita Katsuaki 山下克明. Onmyōdō no hakken 㓌陽道 の発見. NHK Books, 2010.

Yano Michio 矢野道雄. Mikkyō senseijutsu 密教占星術. Tōyōshoin, 2013.

Yano Michio. “'Sukuyō-kyō’ no Daizōkyō hon to wabon no hikaku (kaiseiban) 『宿曜経』の大蔵経本と和本の比 較〔改正版〕. Nihon ko-shakyō kenkyūjo kenkyū kiyō 日 本古写経研究所研究紀要 1 (2016), pp. 1-11. 